\title{
Chewing more than one can swallow: the creation of new districts in Uganda*
}

\author{
DOUGLAS KAREKONA SINGIZA
}

Magistrate, Uganda; Doctoral intern with Local Democracy, State, Peace and Human Security Programme, Community Law Centre, University of the Western Cape

\section{JAAP DE VISSER}

Professor of Law and Project Coordinator of the Local Democracy, State, Peace and Human Security Programme, Community Law Centre, University of the Western Cape

\section{INTRODUCTION}

Local government has become one of Uganda's iconic democratic symbols, especially because of the manner in which the process of decentralisation transfers powers and functions from central government to local government and promotes public participation at the lowest levels through established structures. ${ }^{1}$ Before 1993, when decentralisation was established as a presidential policy, local administration structures represented state autocracy and central government hegemony. ${ }^{2}$ In response to this, the post-1993 decentralisation programme made local government the epitome of democracy in Uganda.

The number of districts, the main local government unit in Uganda, has since grown in leaps and bounds. This article analyses the process of creating districts. It briefly discusses the local government system in Uganda and introduces the phenomenon of the increase in the number of districts. It continues with an analysis of why, in principle, the creation of more districts may be beneficial to Uganda. However, it focuses also on the financial burden that these newly created districts place on the locality and the state and does so in the context of the role of districts in facilitating the realisation of socio-economic rights in Uganda. The article examines the resources needed to sustain a new district and draws conclusions with regard to the impact on the decentralisation programme.

\footnotetext{
* This article is an improved version of a paper that was presented at the Institute of Federalism, University of Freiburg, in August 2009. The authors are grateful to Nico Steytler and Solly Leeman for their helpful comments on an earlier draft and to Tinashe Chigwata for editorial assistance.

1 See the long title to the Local Governments Act Cap 234.

2 Mamdani (1996) 23.
} 


\section{DISTRICTS IN UGANDA}

The system of local government in Uganda is a five-tiered one, consisting of (i) districts, (ii) counties, (iii) sub-counties, (iv) parishes and (v) villages or wards. Only districts, cities, municipalities and sub-counties are legal persons with capacity to sue and be sued and vested with executive and legislative powers. ${ }^{3}$ The Constitution of Uganda provides that the district is the basis of the local government system and that it is a unit under which other lower local government and administrative structures operate. ${ }^{4}$ The autonomy of local government, in other words, finds expression in the powers and functions of districts as the main unit of local governance. ${ }^{5}$ Districts are centres of political and administrative power. ${ }^{6}$ They are constitutionally protected in that any Bill that seeks to amend any of the core provisions relating to districts must be adopted by following a special procedure, including the approval of the districts themselves. ${ }^{7}$

\subsection{District local government councils}

The district council is the "highest political authority" in the area of jurisdiction of local government. ${ }^{8}$ This underscores the significance of the council as a political body rather than an administrative organ. The chairpersonship and the composition of the council are regulated in the Constitution and the Local Government Act (LGA). Article 180(2) of the Constitution states that the district council is chaired by an elected district chairperson. Furthermore, section 10 of the LGA provides for the composition of a district council. The abovementioned district chairperson is a

3 Section 6 of the LGA.

${ }^{4}$ Article 176 (1). See Odoki Constitution Commission Report (1994) 496, para 18.81. See also art 177 of the Constitution which provides:

"(1) Subject to the provisions of this Constitution, for the purposes of local government, Uganda shall be divided into the districts referred to in article 5(2) of this Constitution.

(2) The districts referred to in clause (1) of this article shall be taken to have been divided into the lower local government units which existed immediately before the coming into force of this Constitution."

${ }^{5}$ Section 30(1) of the Local Government Act obliges local government councils, subject to the Constitution, to

"(a) exercise all political and exercise executive powers and functions;

(b) provide services as it deems fit with the exception of functions, powers and services listed under Part I of the Second Schedule to this Act;

(c) protect the Constitution and other laws of Uganda and promote democratic governance; and

(d) ensure the implementation and compliance with Government policy".

6 Article 177 (1) of the Constitution provides:

"(1) Subject to the provisions of this Constitution, for the purposes of local government, Uganda shall be divided into the districts referred to in article 5(2) of this Constitution.

(2) The districts referred to in clause (1) of this article shall be taken to have been divided into the lower local government units which existed immediately before the coming into force of this Constitution".

7 These core provisions are in arts 5(2), 152, 176(1), 178, 189 and 197 of the Constitution.

8 Section 9(1) of the LGA. 
member of the district council. ${ }^{9}$ The law furthermore provides for the election of a constituency representative elected from "an electoral area of a district".10 Vulnerable groups are specifically catered for as the law provides for councillors representing the youth, ${ }^{11}$ the disabled ${ }^{12}$ and the elderly. ${ }^{13}$ The LGA specifically requires that female councillors should form one-third of a Council. ${ }^{14}$ Members of Parliament are ex officio members of the district council in their constituencies. ${ }^{15}$

\subsection{Political and administrative office-bearers}

The Constitution provides for a district chairperson as the political head of a district. ${ }^{16}$ The LGA confers the title of "mayor" on the district chairperson. ${ }^{17}$ The chairperson is directly elected by universal adult suffrage. ${ }^{18}$ This clearly positions him or her as the political head of the local government with political authority emanating from the local community and not from central government.

The Constitution also provides for a speaker for each district council. ${ }^{19}$ According to the LGA the speaker's role is to preside over all meetings of the local government council. ${ }^{20} \mathrm{He}$ or she is charged with the overall authority and supervision of order in the council and ensuring enforcement of rules of procedure. ${ }^{21}$ In other words, he or she performs functions similar to those of the Speaker of Parliament.

Every district has a Chief Administrative Officer(CAO), appointed by the Public Service Commission. ${ }^{22}$ The CAO thus falls under the control and supervision of the Public Service Commission like any other central government civil servant. The qualifications of a $\mathrm{CAO}$, and his or her functions, have to be prescribed by Parliament. ${ }^{23}$ To qualify to be appointed as a CAO a person must have a university degree from a recognised institution ${ }^{24}$ and a diploma in public administration or development studies from a recognised institution. ${ }^{25} \mathrm{He}$ or she must have ten years

\footnotetext{
9 Section 10(1) (a) of the LGA.

${ }^{10}$ Section 10 (1) (b) of the LGA.

${ }^{11}$ Section 10 (1) (c) of the LGA.

${ }^{12}$ Section 10 (1) (d) of the LGA.

${ }^{13}$ Section 10 (1) (f) of the LGA.

${ }^{14}$ Section $10(1)$ (e) of the LGA.

15 Section 10(2) of the LGA.

${ }^{16}$ See article 183 (1) (a) of the Constitution. See also section 12 (1) (b) of the LGA.

17 Section 15 of the LGA.

${ }^{18}$ See art 183 (1) (b) of the Constitution.

${ }^{19}$ See art 184 of the Constitution. See the Odoki Commission (para 18.116 p 502).

${ }^{20}$ Section 11 (9)(a) of the LGA

21 Section 11 (9) (b) of the LGA.

${ }^{22}$ See art 188 of the Constitution.

${ }^{23}$ Article 198(3) of the Constitution. See also Tommy Obongo Ojok v Apac District Local Government HCT-02-CV-CS-0015-(2005).

${ }^{24}$ Section 63 (2) (a) of the LGA.

${ }^{25}$ Section 63 (2) (b) of the LGA.
} 
working experience ${ }^{26}$ and must be of high moral calibre. ${ }^{27}$ Thus, significant competency and experience requirements apply to the office of CAO.

\subsection{Devolved functions of local government}

Under Part I of the Second Schedule to the LGA districts are mandated to perform a range of functions. They provide education services as well as medical and health services by running hospitals. They are furthermore tasked with the provision of maternity and child welfare services and the control of communicable diseases such as HIV/AIDS, leprosy and tuberculosis. Districts must control the spread of diseases and provide rural ambulance and primary health care services. Hence districts are important structures in the public health sector. In addition, districts provide water services, including the maintenance of water supplies in liaison with the relevant line ministry. Finally, districts are required to provide road services.

\subsection{The increase in the number of districts in Uganda}

Uganda has a population of about 29.7 million people. ${ }^{28}$ There are now 112 districts in Uganda, up from 33 when the current regime came into power 23 years ago. ${ }^{29}$ This translates into an average of 371250 people per district.

An overview of the number of districts over the last decades indicates a progressive increase. For example, between 1986 and 199711 new districts were created. In 2000,11 new districts were created while in 2005, the year preceding the 2006 elections, 22 new districts were created. In 2006, the year following the elections, 9 districts were created, and the total number had grown to 112 by the end of 2010, up from 79 in 2006.30 The year-on-year percentage growth in the number of districts is outlined in Table 1 (on $\mathrm{p} 5$ below).

\section{WHY MORE DISTRICTS COULD WORK WELL}

Establishing more local government units is aimed at creating more space for nurturing democracy and to stimulate development and service delivery at the local level by creating closer proximity between communities and local government. The policy rationale for enhancing the number of local government units is intimately connected to the debate about the advantages and disadvantages of devolution.

\footnotetext{
${ }^{26}$ Section 63 (2) (c) of the LGA.

${ }^{27}$ Section 63 (2) (d) of the LGA.

${ }^{28}$ Bahemuka (2006) 8.

${ }^{29}$ The Daily Monitor (21 July 2009).

30 See List of Districts, Municipalities and Town Councils in Uganda as of July 2010 at http://molg.go.ug/2010/11/05/list-of-districts-municipalities-and-town-councils-in-uganda-as-ofjuly-2010/(accessed 27 May 2011).
} 
Table 1: Growth of the number of districts, $1962-2010$

\begin{tabular}{|lcc|}
\hline Year & No of Districts & \% of growth of Districts \\
\hline 1962 & 17 & - \\
\hline 1968 & 18 & $6 \%$ \\
\hline 1971 & 19 & $6 \%$ \\
\hline 1974 & 37 & $95 \%$ \\
\hline 1979 & 33 & $-11 \%$ \\
\hline 1990 & 34 & $3 \%$ \\
\hline 1991 & 38 & $12 \%$ \\
\hline 1994 & 39 & $2.6 \%$ \\
\hline 1997 & 45 & $15 \%$ \\
\hline 2000 & 56 & $24 \%$ \\
\hline 2005 & 70 & $25 \%$ \\
\hline 2006 & 79 & $13 \%$ \\
\hline 2010 & 112 & $42 \%$ \\
\hline
\end{tabular}

Source: ACODE Policy Research Series No. 27 (2009) 42; 2010 figures provided by the authors.

\subsection{Democracy}

Democracy is both a constitutional value and a process. The value of democracy lies in the making of good decisions through the right procedures. ${ }^{31}$ Democracy as a process affords voters the power to select their leaders and allows them to participate in decision-making. Briffault argues that local government units are "hatcheries" for democracy because it costs less to "reach out, engage, and persuade" people in smaller units of government than in bigger ones. ${ }^{32}$ It may then follow that smaller local government units are better for the nurturing of a democratic culture.

\subsection{Accommodation of diversity}

Conventional theory about state-building long asserted that national interests are subordinate to ethnic or regional autonomous governance and identity demands. ${ }^{33}$ Strong autonomous powers for ethnically defined local government units would exacerbate ethnic tensions and contribute to national disintegration. ${ }^{34}$ However, it is also argued that neglecting the wishes of an identifiable ethnic and/or cultural group may lead to demoralisation and alienation. Where a group has been alienated politically at a national level, pursuing political claims at the local level then becomes a logical option. ${ }^{35}$

This avenue for diverse ethnicities and cultures to assert their identity politically may ultimately serve to bind a country together. A link can be drawn to the theory of

\footnotetext{
${ }^{31}$ Sypnowich (2007) 765.

32 Briffault (1996) 1124.

${ }_{33}$ Howard (1991) 412-19.

${ }^{34}$ Bayart (1993) 41-59.

35 Kymlicka (1995) 135.
} 
political accommodation through asymmetric federalism. Miller refers to the recognition of ethnic interests in a country as a kind of "nested identity". He refers to Québec's special federal status in Canada which perhaps represents the most classic example of asymmetric political accommodation of a distinct cultural group. He argues that Quebec has one part of its identity in the federal province and the other part of its identity in the rest of Canada. ${ }^{36}$ Writers such as Fessha make a case for asymmetrical federalism as a remedial measure that is designed to address deeper and politicised ethnic interests. Fessha characterises such a federal design as "purpose continuum" federalism of which the aim is to guard against possible secession of an ethnic group within a nation. ${ }^{37}$ In the context of this debate, increasing the number of local government units may serve to accommodate diverse ethnicities and cultures.

\subsection{Good governance}

The concept "good governance" rose to prominence in the 1990s as a result of the World Bank's policy of emphasising the proper exercise of political power in order to better manage a nation's affairs. ${ }^{38}$ The World Bank took the view that good governance is a precursor to development. Thus, according to the World Bank, good governance must relate to the exercise of political power for development. ${ }^{39}$ According to Botchway, good governance comprises of a range of values such as accountability, transparency, anti-corruption measures, rule of law, advancement of women, democracy and decentralisation. ${ }^{40}$ The International Monetary Fund (IMF) uses good governance as a precondition for financial support to national governments as well as local governments. ${ }^{41}$ Good governance is also posited as a means to eradicate poverty. For example, the United Nations Development Program (UNDP) argues that "it is only with good governance that we can find solutions to poverty, inequity and insecurity". 42

In making the link between good governance and increasing the number of local government units, it can be argued that closer proximity of communities to their leaders promotes good governance. Communities can demand explanations more quickly and more easily from smaller local government units than from bigger local government units. Downsizing local government units may also enhance the state's ability to address poverty as decision-making at the lowest levels is better able to synchronise development with the needs of communities.

\footnotetext{
${ }^{36}$ Miller (1998) 66.

${ }^{37}$ Fessha (2010).

38 World Bank (1989) 60-62.

39 World Bank (1997) 41-60.

40 Botchway (2001) 3.

${ }^{41}$ See generally IMF (1997).

42 UNDP 2008. See Amanda (1999) 21-22 for a contrary view.
} 


\subsection{Economic management and political economy}

Another useful prism through which to assess devolution is the distinction made by Loughlin between the economic management approach and the political economy approach. ${ }^{43}$ The economic management approach examines the distribution of income, the maintenance of a stable economy and the efficient allocation of resources. Devolution of power is permissible as long as it reduces costs, promotes efficient production and does not subvert the supra-structural arrangement for stability and predictability. ${ }^{44}$ The view of the political economy school is broader. It considers both economic and political power as important components for the devolution of powers and functions from central government to local government. The political economy approach emphasises that powers and functions which devolve to local governments should be clear and unambiguous with little room for unnecessary overlaps. It holds that devolution is sensible only if there is capacity on the part of the decentralised unit to utilise the devolved power. Capacity is then defined in terms of resources. ${ }^{45}$ Devolved power is an empty shell if it is not accompanied by the power to collect and utilise revenue. The political economy approach also argues against devolution without mechanisms to limit corruption and abuse of power as this type of devolution does not produce economic benefit.

The fiscal capacity of local government units is central to the success of any decentralisation programme. Fiscal capacity generally comprises own revenue, collected by the local government unit and additional resources allocated by the centre. Decentralisation is only sustainable if it can be linked to budgetary practices that are coherent and disciplined. The allocation of resources from the central government to local government units is a further key determinant in the decentralisation programme. Central governments generally distribute resources to local government units based on factors such as interregional equity, availability of resources and local fiscal management capacity. An increase in the number of local government units results in additional pressure on the intergovernmental fiscal framework to maintain more political and administrative structures. The intergovernmental fiscal framework must be able to absorb this change without short-changing communities which depend on the state to use its revenue towards development and service delivery.

\section{ASSESSING THE CREATION OF DISTRICTS IN UGANDA}

What follows is an assessment of the creation of districts in Uganda against the backdrop of the above arguments.

\footnotetext{
${ }^{43}$ Loughlin (1986) 1-4.

${ }^{44}$ Loughlin (1986) 1-3.

45 Botchway (2001) 31.
} 


\subsection{Democracy}

The demarcation of local authority boundaries is an important component of the process of democratic devolution. The demarcation delineates electoral boundaries and determines the size of the unit of local democracy.

The Constitution provides for demarcation of a district into electoral areas in an equal manner according to the number of inhabitants. ${ }^{46}$ However, this may vary due to logistical factors, such as communication, geographical features and population density. ${ }^{47}$ The demarcation of electoral areas is subject to Article 181 of the Constitution. Demarcation takes place according to a number of criteria. The number of inhabitants and the need to ensure that women constitute one-third of any local council plays a prominent role. ${ }^{48}$ What the above provision means is that a district is a basic unit within which electoral areas are determined. Furthermore, counties in a district are usually constituencies for national elections. Ultimately, creating new districts inevitably increases the number of new national constituencies, since new counties have to be created as constituencies for national elections.

The demarcation of districts is governed by the 1995 Constitution. ${ }^{49}$ Parliament is empowered to alter district boundaries or to create new ones. ${ }^{50}$ Changes in or alteration of boundaries must be supported by the majority of the members of Parliament. ${ }^{51}$ Demarcation is based on three factors. First, the change or alteration to a district boundary must be based on the need for effective administration. Secondly, it must be based on the need to bring services closer to the people. Thirdly, the means of communication, geographical features, population density, economic viability and the "wishes of the people concerned" must be considered. ${ }^{52}$ There is no specific injunction on Parliament to assess these wishes through a consultative procedure.

Despite the existence of criteria for creating new districts, there is evidence that some of the newly-created districts serve as inducements to communities to vote for a specific political party (usually the ruling party). As long as the ruling party has the numbers in Parliament that it does, ${ }^{53}$ it can create as many districts as it wants without a significant input from independent stakeholders. The process of the creation of districts was assessed as follows in a recent report:

\footnotetext{
${ }^{46}$ Section 181 (1) of the Constitution.

${ }^{47}$ Section 181 (2) of the Constitution.

${ }^{48}$ Section 108 (1) and (3) of the LGA.

${ }^{49}$ Article 179 of the Constitution.

${ }^{50}$ Article 179 (1) (a) and (b) of the Constitution.

${ }^{51}$ Article 179 (2) of the Constitution.

${ }^{52}$ Article 179 (4) of the Constitution.

${ }^{53}$ Currently the ruling National Resistance Movement (NRM) has a two-thirds majority in Parliament.
} 
"The creation of the districts did not follow any established parameters, neither was the process informed by administrative necessity or economic rationale. Instead, the President announced their creation via presidential decrees, often to reward politicians threatening to withdraw support for the NRM, or to punish those who had." 54

A process combining objective examination and public hearings would be able to determine if democracy is indeed strengthened by the creation of more districts. However, thus far, there has not been any evidence that the creation of these many districts for reasons of political expediency serves any democratic purpose.

\subsection{Accommodation of diversity}

Critics of the creation of more districts in Uganda often express concerns with regard to the creation of districts on the basis of tribal and sectarian considerations. ${ }^{55}$ These concerns usually arise even before legal and economic concerns are considered. It is argued here that the Constitution of Uganda calls for the accommodation of diversity and, furthermore, that the creation of districts that recognise ethnic or cultural diversity should not be condemned solely for that reason. This argument is based on the Constitution; article 10(a) of the Constitution, read with the Third Schedule to the Constitution, recognises 65 indigenous communities. A key question for the Ugandan state, operating under the auspices of its Constitution, is how to recognise the diversity of these communities and what role the creation of districts plays in that regard.

The Constitution contains a number of additional pointers to the importance of recognising diversity. First, the preamble to the Constitution uses the first person plural "we", highlighting the diverse nature of the Ugandan society. Second, in part III of the directive principles of state policy the Constitution aspires to integrate all people in Uganda, while recognising the existence of diverse cultures and ethnicities, among others. Thus, "[e]verything shall be done to promote a culture of cooperation, understanding, appreciation, tolerance and respect for each other's customs, traditions and beliefs". ${ }^{56}$ In that context, the Constitution aspires to protect marginalised groups. ${ }^{57}$

The Constitution obliges each regional government to recognise and to respect the different cultures existing within a region..$^{58}$ The promotion of local democracy at the level of districts that reflect ethnic diversity may serve to increase a sense of

\footnotetext{
${ }^{54}$ ARD (2005) 41.

55 See The Daily Monitor (15 July 2009) where it was reported that a cabinet Minister threatened to resign if district headquarters were allocated to a different area, a position he admitted was based on tribal sentiments. See also "Leave out Tribalism in the Creation of Districts" New Vision (24 June 2009), available at http://www.newvision.co.ug/D/8/14/685770 (accessed 27 May 2011).

56 See directive objective principle of state policy No.III.

57 See directive objective principle of state policy No.III.

58 See art 12 (1) of the Constitution.
} 
involvement of a particular minority group in the affairs of the state. It may be argued that the creation of districts with boundaries that recognise the existence of these groups as envisaged by the Constitution may correspond to such constitutional values and principles. Three examples are briefly introduced to illustrate this point. First, the Batwa in South-Western Uganda are a minority group that would arguably deserve the protection afforded by the Constitution. ${ }^{59}$ They have a distinct culture expressed through their language and religion. The BaruliBanyala is another example. They are mainly found in the new districts of Nakasongola and Kayunga. Historically, they had their own culture and language identity but were "assimilated" into the Buganda culture during the time of the British colonial administration. 60 The Banyala have a distinct language that is different from the language of the Baganda. In addition, the Banyala oral tradition claims that they are the descendants of the "Creator" or God or Ruanga, ${ }^{61}$ demonstrating a special attachment to faith and belief in a supernatural being. The third example is provided by the Nubians. They were long considered as part of the Acholi community but have a distinct religious, cultural and linguistic identity. The Nubians have a distinct language with a strong Islamic culture.

The distinct features of these three minority groups may require institutions that ensure that they can elect leaders that indentify with their unique cultures languages and faith. This is possible where districts are specifically created to make sure that communities can participate in local politics with which they can identify. Secondly creating districts for minority groups ensures that their unique development needs such as hunting, fishing and protection of the environment can be better addressed. In addition, creating districts for minority groups may provide the institutional framework necessary to facilitate education in a language of choice.

\subsection{Realisation of socio-economic rights}

In addition to the call for the recognition of diversity, the Constitution also includes a call for the extension, development and realisation of socio-economic rights. Although these rights are not justiciable, in the objective principles of state policy the Constitution undertakes to respect socio-economic rights in the future. ${ }^{62}$ Secondly, Uganda is a signatory to the International Covenant on Economic, Social and Cultural Rights (ICESCR) ${ }^{63}$ which lays down standards for the realisation of socio-economic rights.

It is clear that the functions of a district intersect with the objective principles of state policy with regard to socio-economic rights and certainly with the rights

\footnotetext{
${ }^{59}$ See generally Kabananukye \& Kwagala (2007).

${ }^{60}$ Nakayi (2007) 20.

${ }^{61}$ Nakayi (2007) 20.

${ }^{62}$ See National Objectives and Directive Principles of State Policy no 14 (a) and (b).

${ }^{63}$ See the list of countries that have ratified the (ICESCR) available at http://treaties.un.org/Pages/ ViewDetails.aspx?src=TREATY\&mtdsg no=IV-3\&chapter=4\&lang=en (accessed 27 May 2011).
} 
contained in the ICESCR. As mentioned above, every district is vested with the function to provide education services. This means that districts play an important role in the realisation of the right to education as a socio-economic right. Districts are also vested with the function to provide medical and health services by running hospitals, providing maternity and child welfare services and controlling communicable diseases such as HIV/AIDS, leprosy and tuberculosis. The function to provide the above services is equally important in the realisation of the right to health, particularly the promotion of the right to maternal and child health under international law. In addition, districts are vested with the function to provide water services, including the maintenance of water supplies in liaison with the relevant line ministry.

Clearly the districts' function to provide water services places districts at the centre of the realisation of the right to water. The question asked in this article is whether the Ugandan state, in facilitating an almost exponential growth in the number of districts, is frustrating its ability to realise these socio-economic rights. Reports on one of the newly created districts paint a grim picture:

"For more than 10 months now, Luuka District, which has a population of more than 200,000 people, continues to manage without a single medical doctor, Daily Monitor has learnt. As a result, the delivery of healthcare services is severely hampered. Only a single health centre (...) exists in the new district carved out of Iganga but renders services not befitting for a facility of its grade." 64

Oloka-Onyango remarks that "the strategy of district proliferation has also been adopted by President Museveni as a means of dispensing patronage, and ultimately of splintering challenges to the central government hegemony and control".65 Thus, rather than ensuring the realisation of socio-economic rights, the objective of the creation of districts appears to be to benefit a few local politicians in the new districts in order to strength the central government's political clout.

The Constitution allocates functions to districts to provide services which are important in the realisation of socio-economic rights. At the same time, the Constitution adheres to a socio-economic rights paradigm. This demands that the district commands adequate human resources, technical capacity and financial resources to execute its tasks. What follows is an examination of the impact of the growth in the number of districts on these human resources, technical capacity and financial resources and thus on the ability of the district governance system to contribute to the realisation of these socio-economic rights.

64 The Daily Monitor (7 April 2011) at http://www.monitor.co.ug/News/National/-/688334/ 1140316/-/c2sydnz/-/index.html (accessed 27 May 2011).

65 Oloka-Onyango (2007) 12. 


\subsection{Human resources}

Every district must have a district chairperson as the political head, a vicechairperson, a speaker and deputy speaker and councillors including those councillors that cater for special interest groups such as women, the youth, the disabled and the elderly. Furthermore, a range of local government units operate under the district. Some of these units are political bodies and others are mainly administrative. Oloka-Onyago estimated that by 2007 (when the number of districts stood at 79), Uganda had a total of 50000 political and administrative local government units across all levels of local government.66 With the number of districts now standing at 112, it can be estimated that the current number of local political and administrative units (excluding support staff) may stand at 90000 . It has been argued that this makes Uganda one of the most "over governed countries in sub-Saharan Africa". ${ }^{67}$

In addition, every district must have a Chief Administrative Officer or CAO as accounting officer. Provision is made for a deputy and assistant CAO in every district. Moreover, for every district provision is made for a Central Government Representative ${ }^{68}$ and a district woman member of Parliament. ${ }^{69}$ Creating a new district means that each of the above political and administrative offices is created. It also means that the number of councillors increases. Each district requires the services of a district engineer, to mention but a few. This capacity requires time to develop. It may thus be argued that the creation of new districts strains existing capacity to realise the above socio-economic rights.

It is important for district councils to be populated with capable councillors. District councillors should be literate. They should be knowledgeable in simple arithmetic, be computer literate and be able to analyse complicated documents such as budgets and financial statements. The above skills are critical to the performance of the council's oversight role. The debate about minimum education standards for elective posts illustrates that the quality of district councillors is a challenge in Uganda. For example, Kanyeihamba bemoans the failure to set minimum education standards for all elective posts:

"because the majority of voters in the country are either illiterate or possess minimal educational qualifications and in order to please them and covet their votes, many political leaders shy away from rewarding those who struggled to be educated. In any event, a nation can only develop and prosper if the majority of its leaders both at the national and local levels are enlightened through education and reading. The tolerance and acceptance of mediocrity in our elections have meant a

\footnotetext{
66 Oloka-Onyango (2007) 12.

67 Tumushabe (2009) 40.

${ }^{68}$ Article 203 of the Constitution.

${ }^{69}$ Article 78(1)(b) of the Constitution.
} 
temptation on the part of those who do not qualify under the very minimum standards, to cheat and forge educational certificates and diplomas". ${ }^{70}$

The conclusion is that the creation of too many districts increases the pressure on the capacity of the local government system to produce quality district councillors in a context where the system is already struggling to populate the existing seats with high calibre representatives.

\subsection{Technical capacity and performance}

Uganda struggles with a high illiteracy rate, low levels of income, high levels of malnutrition, high levels of unemployment, a high infant mortality rate and low life expectancy. ${ }^{71}$ It is most likely that a considerable number of people who are elected as district councillors may consider their new offices as a means to escape poverty. It is especially troubling in this respect that the Auditor-General's Report of 2009 notes widespread financial mismanagement and corruption in local government. The report notes, among other things, the concealment of cash transactions from scrutiny, under-collection of local government revenue, excessive expenditure without authority, poor accountability, unvouched expenditure, irregular procurement of goods and services, non-remittance of taxes to the Uganda revenue authority (URA), diversion of funds and wasteful expenditure. ${ }^{72}$

The 2009 Annual Assessment of Minimum Conditions and Performance Measures for Local Governments assessed local governments in areas such as compliance levels with legal and policy guidelines in finance and accounting, procurement and disposal regulations, capacity to manage discretionary development funds etc. ${ }^{73}$ The outcome of this assessment by national government is used to decide on penalties and rewards in the realm of intergovernmental transfers and the like. The report paints a grim picture. Of the 80 districts, only $42 \%$ were rewarded for good performance, $30 \%$ were labelled "static", meaning there was no improvement, while $28 \%$ were penalised for underperformance. ${ }^{74}$

\subsection{Financial resources}

The main sources of revenue for a local government are taxes, grants from the central government and loans. ${ }^{75}$ Local governments may levy "rents, rates, royalties,

\footnotetext{
70 Kanyeihamba (2002) 265-266.

${ }^{71}$ See generally Emwanu et al (2008). See also Bahemuka et al (2006).

${ }^{72}$ See Annual Report of the Auditor General for the Year ended 30th June 2009 Volume 3 Local Authorities p 7-47.

${ }^{73}$ See Annual Assessment of Minimum Conditions and Performance Measures for Local Governments 2009: Synthesis Report March (2010) 8.

74 See the Annual Assessment of Minimum Conditions and Performance Measures for Local Governments 2009: Synthesis Report March (2010) 9.

75 See arts 191(2), 193 and 195 of the Constitution.
} 
stamp duties, cess, ${ }^{76}$ fees on registration and licensing and any other fees and taxes that Parliament may prescribe". ${ }^{77}$

Local government depends to a large extent on the grants allocated by the central government. Own revenue plays a less prominent role. For instance, the Rukungiri district budget in the 2010/2011 financial year indicates that sh17bn (approximately US\$ 7150 000) will be spent, up from sh12bn (or approximately US $\$ 5000$ 000) spent in $2009 / 2010$. Of this amount, the central government will fund about $98 \%$ of the budget, while the local governments' own revenue contribution is $1.6 \%$ of the budget. ${ }^{78}$ This figure compares well with the national average of local government revenue contribution vis-à-vis the central government transfers on one hand and donor/NGO funding on the other.

The Constitution spells out three types of transfer: (i) unconditional grants, (ii) conditional grants and (iii) an equalisation grant. ${ }^{79}$ Each year, the central government must present a proposal to Parliament as to the monies to be paid out of the Consolidated Fund for such grants. 80

An unconditional grant is the minimum grant that the central government pays to local government. ${ }^{81}$ Each of these grants has a specific purpose for which it is allocated. According to the Constitution, unconditional grants serve to deliver decentralised services and, unlike other grants, are distributed according to a specific formula. ${ }^{82}$ The formula considers the previous financial year's transfer, inflationary trends and the cost of running services. ${ }^{83}$ It has been argued that unconditional grants, although recognised as local government revenue, are not a sustainable source of revenue. ${ }^{84}$

Conditional grants are payments made by central government pursuant to an agreement between central government and local government. They are expended subject to conditions specified in the agreement. ${ }^{85}$ Strictly speaking, they are not

\footnotetext{
${ }^{76} \mathrm{~A}$ "cess" as a local tax has its origin in agricultural activities, such as cotton ginning, but is generally collectable on produce, which by presidential proclamation has recently been banned. See CA debates (p 3881). See also Musoke C "Museveni bans farm produce tax" The New Vision (5 March 2010).

${ }^{77}$ Articles 191(2), 193 and 195 of the Constitution.

78 The New Vision (24 June, 2010).

${ }^{79}$ See art 193(1) of the Constitution.

80 See art 83(1) of the LGA.

81 See art 193 read together with the Seventh Schedule to the Constitution.

82 See art 193(2) of the Constitution. The Seventh Schedule offers a further explanation for unconditional grants: an "unconditional grant is equal to the sum of wage and non-wage components. Therefore, the wage components should be adjusted for the wage increase, if any, while the non-wage component is adjusted to the changes in the general price levels".

${ }^{83}$ See reg 55 (1) of the LGFR.

${ }^{84}$ Wash \& Ottenoeller (2004) 196.

${ }^{85}$ See art 193(3) of the Constitution.
} 
considered part of local government revenue. ${ }^{86}$ In fact, conditional grants must be separately budgeted for from other sources of local government revenue. ${ }^{87}$ In addition, conditional grants are accounted for on conditions agreed to between the central government and local government. ${ }^{88}$ Ugandan analysts argue that local government is too dependent on conditional grants as a main source of funding. They argue that the conditional grant is a form of subtle recentralisation aimed at reversing the gains of devolution of powers to local government. ${ }^{89}$

Equalisation grants are payments made to local governments from the central government as a form of subsidy for least developed districts. The basis on which equalisation payments from central government are made is service-specific. ${ }^{90}$ They are based on the degree of economic disparity between the district and the national average standard of a particular service. ${ }^{91}$

The figure below shows the trends of central government transfers from 2001 to 2008. It shows stagnation in the equalisation grants, a fluctuation in unconditional grants and a steady increase in conditional grants. Implicitly the figure demonstrates that local government depends to a large extent on central government transfers.

Figure 1: Trends of Central government transfers to Local governments.

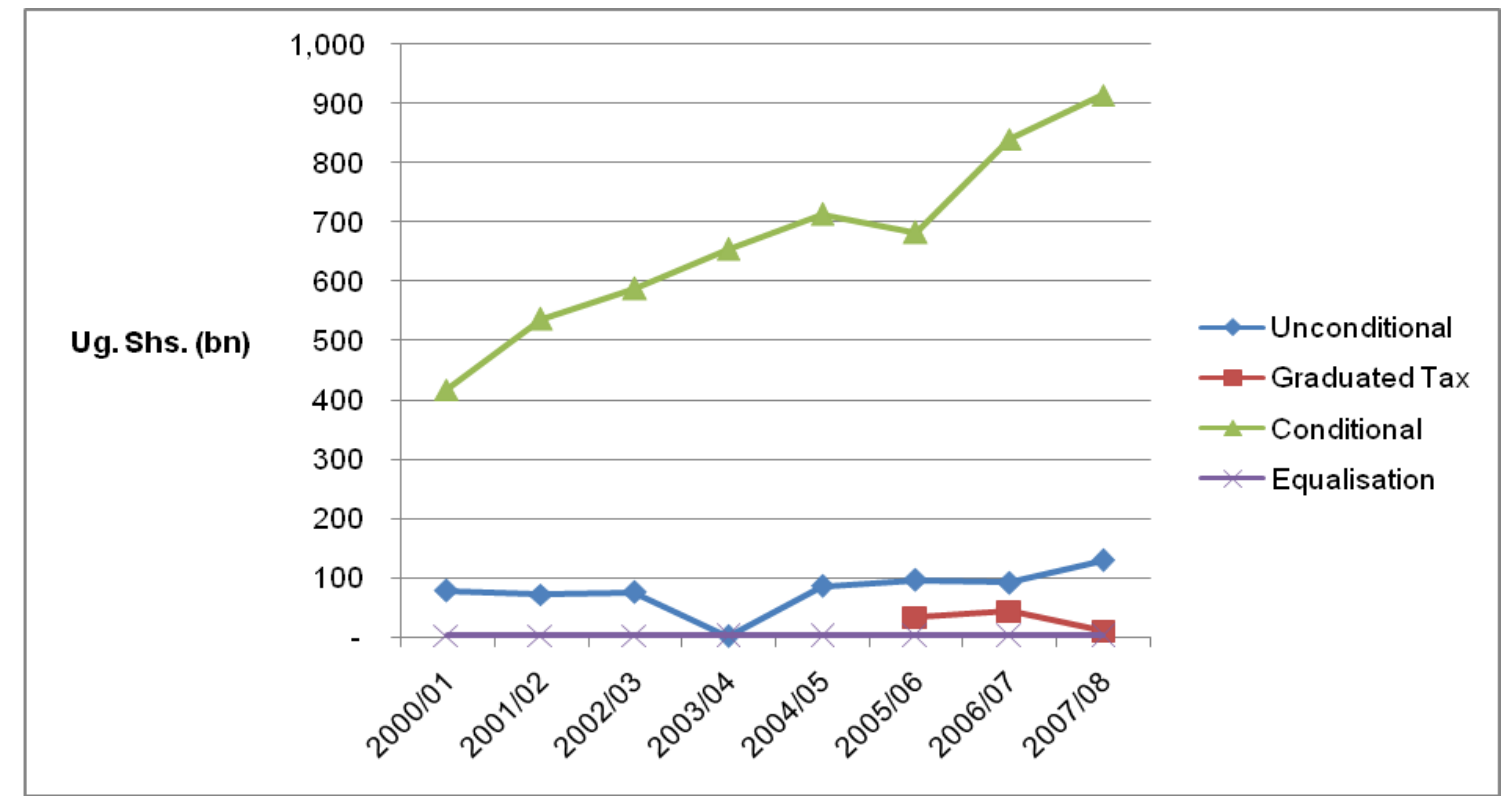

Source: Fiscal decentralisation budget release performance - FY 2008/09 volume I, Issue 3

\footnotetext{
$86 \quad$ See Regulation 55 (1) of the LGFR.

$87 \quad$ See Regulation 55 (2) of the LGFR.

88 See Regulation 55 (3) of the LGFR.

89 Tusasirwe(2007)31.

$90 \quad$ See Regulation 55 (4) of the LGFR.

91 See Art 193(4) of the Constitution.
} 
It is estimated that the wages and the salaries alone for a new district cost Shs1.2 bn (US\$500 000) per annum. This means that about Shs28.8 bn (US $\$ 14$ million) is being consumed by the 24 new districts created between 2004 and 2009.92 There is no doubt that the creation of new districts has put greater pressures on local governments' staff expenditure and has diverted resources needed for service delivery to administrative and salary costs. ${ }^{93}$ This is compounded by the fact that central government's allocation to local government as a percentage of public expenditure has declined from around 47 per cent in 2001/02 to only about 22 per cent in 2008/09.94 Therefore, even without the extra districts to support, local government receives less money from the national pie.

It could be argued that the increase in the number of districts enables the central government to develop a system for more refined disbursement of subsidies for the least developed districts. However, the creation of districts which are wholly dependent on central government transfers results in greater dependency and ultimately does not enhance local democracy. It is likely that the new districts will become burdensome to the central government.

\section{TOWARDS THE INDEPENDENT DEMARCATION OF DISTRICTS}

It is clear from the above that the process of demarcation of districts and the outcome of recent demarcation activity are problematic. It is suggested that an independent boundary demarcation body should be established. This is to ensure that the process is free from political manipulation. Furthermore, the process of demarcation of district boundaries should be made more transparent and participatory. The basis for which re-demarcation is sought must be made clear to the communities affected. The criteria for drawing new ones or keeping old ones ought to respect existing boundaries, including traditional authority boundaries, administrative considerations and service delivery factors. In addition, the boundary demarcation process needs to respect principles and criteria such as the promotion of democratic citizenship, improvement of efficiency, the territories occupied by specific cultural, linguistic or ethnic communities and the powers and duties that should be devolved to local governments. ${ }^{95}$

In South Africa, for instance, municipal boundaries are determined by a Municipal Demarcation Board appointed by the President. The Board operates independently from the legislative and executive branches and has its own legislative mandate. The Local Government: Municipal Demarcation Act ${ }^{96}$ makes provision for any person aggrieved by a proposed boundary changes to object in writing. The Board must

92 Kadiresan \& Onyach-Olaa (2009).

${ }^{93}$ Kadiresan \& Onyach-Olaa (2009).

${ }^{94}$ See 2009-2010 budget estimates of Uganda.

95 Briffault (1996) 1123-1133.

${ }^{96}$ Act 27 of 1998. 
consider those objections and "either confirm, vary or withdraw its determination". ${ }^{97}$ In addition, the Board is required to solicit views on any changes of boundaries from local stakeholders by holding public meetings and investigations. ${ }^{98}$

It is recommended that article 179 (4) of the Constitution of Uganda should be amended to provide for an independent body to demarcate district boundaries. This body should be able to operate free from political influence. Hence, any proven attempt at political influence should be subject to criminal prosecution and possible legal sanction. Secondly, the amendment should include a provision for public hearings and objections from members of the public and stakeholders so that the "wishes of the people" are heard before a new district is created.

\section{CONCLUSION}

This article is premised on the need to strengthen democracy by devolving powers to local government. This can be done, as is the case in Uganda, by devolving powers to districts. The creation of more districts could be seen as a vote of confidence in districts and in the institutions of local government. It may promote public participation and affirm local democracy as a sine qua non for development. In addition, the creation of districts that express ethnic or cultural identity should not be rejected just on the basis that they threaten national unity.

However, many of the districts that have been created in Uganda are not financially viable, considering their revenue base and their entitlement to a shrinking share of nationally-generated revenue. As a result, the benefits anticipated from the creation of more districts are not materialising. Despite the fact that the creation of new districts is made dependent on factors such as "the wishes of the people", it appears that the benefits of the creation of new districts accrue to a small number of people gaining access to political or administrative office.

It is therefore suggested that new districts should only be created following sound economic and financial judgments and not purely on the basis of political and tribal expediency. The recent history of the creation of districts indicates that Uganda's national executive and legislative branches are not well-placed to display the level of restraint and due consideration required for this task. It is therefore recommended that the creation of new boundaries and the alteration of existing district boundaries should be left to an independent body with constitutionally guaranteed powers.

\footnotetext{
${ }^{97}$ See s 21 of the Municipal Demarcation Act.

${ }^{98}$ See ss 27- 30 of the Municipal Demarcation Act.
} 


\section{BIBLIOGRAPHY}

\section{Ugandan legislation}

1995 Constitution of the Republic of Uganda.

Local Governments Act, Cap 234.

\section{South African legislation}

Local Government: Municipal Demarcation Act 27 of 1998.

\section{Books}

Amanda J "International Economic Organizations and the Modern Law and Development Movement" in Seidman et al (eds) Making Development Work: Legislative Reform for Institutional Transformation and Good Governance London: Kluwer Law International (1999).

Bahemuka S et al (eds) The 2002 Uganda Population and Housing Census, Population Dynamics Kampala: Uganda Bureau of Statistics (2006).

Bayart J The State in Africa: The Politics of the Belly Longman (1993).

De Visser J Developmental Local Government: A Case Study of South Africa Oxford: Hart (2005).

Fessha Y Ethnic Diversity and Federalism: Constitution Making in South Africa and Ethiopia Ashgate (2010)

Kanyeihamba G Constitutional and Political History of Uganda: From 1994 to the Present Kampala: Centenary Publishing House (2002).

Kymlicka W Multicultural Citizenship: A Liberal Theory of Minority Rights New York: Oxford University press (1995).

Loughlin M Local Government in the Modern State London: Sweet \& Maxwell (1986).

Mamdani M Citizen and Subject: Contemporary Africa and the Legacy of Colonialism New Jersey: Princeton University Press (1996).

Miller D "Secession and the Principle of Nationality" in Moore, M National SelfDetermination and Secession Oxford: Oxford University Press (1998).

Wash J \& Ottenoeller D "Uganda: Multiple Levels of Local Government" in Olowu D et al (eds) Local Government in Africa: The Challenges of Democratic Decentralization Boulder: Lynne Rienner Publishers (2004).

World Bank Sub-Saharan Africa: From Crisis to Sustainable Growth Washington: The World Bank (1989). 
World Bank World Development Report: the State in a Changing World Washington: The World Bank (1997).

\section{Journal articles}

Botchway F "Good Governance: the Old, the New, the Principle, and the Elements" (2001) 2 Florida Journal of International Law 159-210.

Briffault R "Our Localism: Part II--Localism and Legal Theory" (1990) 90 Columbia Law Review 90.

Briffault R "The Local Government Boundary Problem in Metropolitan Areas" (1996) 48 Stanford Law Review 1115-1171.

Howard R "The Full-Belly Thesis: Should Economic Rights Take Priority Over Civil and Political Rights? Evidence from Sub-Saharan Africa" (1983) 5 Human Rights Quarterly 467-490.

Sypnowich C "Ruling or Overruled? The People, Rights and Democracy" (2007) 27 Oxford Journal of Legal Studies 757.

\section{Working Papers}

Kabananukye K \& Kwagala D Culture, Minorities and Linguistic Rights in Uganda: The Case of the Batwa and the Ik HURIPEC Working Paper (2007) available at http://www.huripec.mak.ac.ug/working paper 11.pdf (accessed 27 May 2011).

Nakayi R "Decentralisation and the situation of selected Ethnic and Racial Minorities: a Human Rights Audit" HURIPEC Working Paper (2007) 15.

Oloka-Onyango J “Decentralisation Without Human Rights?" Local Governance and Access to Justice in Post-Movement Uganda" HURIPEC Working paper (2007) 12.

Tumushabe G "Trends in Public Administration Expenditure in Uganda: The Cost of the Executive and its Implications on Poverty Eradication and Governance" ACODE Policy Research Series (2009) 27.

Tusasirwe B "Enforcing Civil and Political Rights in a Decentralized System of Governance" HURIPEC Working Paper (2007) 14.

\section{Newspaper articles}

Abimanyi K. "Uganda"s Districts Grow Beyond Size" Daily Monitor November 12, 2009

Kadiresan K \& Onyach-Olaa M. "Are We Serious on Improving Service Delivery in Local Govts" The Daily Monitor. Available at http://www.monitor.co.ugn/ artman/publish/opinions/Areweseriousonimprovingservicedeliveryinlocalgovts 83936.shtml (accessed 28 April 2009). 
Mugerwa, Y."Government Tables Bill to Take Over Kampala" The Daily Monitor. Available at http://www.monitor.co.ug/artman/publish/news/Govttables BilltotakeoverKampala87025.shtml (accessed on May 2009).

Naturinda S. "Dr Otaala Runs Amok Over Tororo" The Daily Monitor. Available at http://www.monitor.co.ug/artman/publish/news/DrOtaalarunsamokoverToror o88080.shtml (accessed 30 August 2009).

Osinde, M. "Not All Jopadhola Reject Splitting of Tororo District" The Sunday MONITOR at http://www.monitor.co.ug/artman/publish/insights/notalljopad holarejectsplittingoftororodistrict 86387.shtml (accessed 27 May 2009).

Ssegawa M "No doctor for 200,000 people in new district" The Daily Monitor $7^{\text {th }}$ April 2011, available at http://www.monitor.co.ug/News/National//688334/1140316/-/c2sydnz/-/index.html (accessed 23 May 2011).

\section{Other sources}

ARD Democracy and Governance Assessment: Republic of Uganda, 2005 USAID, Kampala (2005).

Emwanu et al "Spatial Trends of Poverty and Inequality in Uganda: 2002-2005" Uganda Bureau of Statistics and the International Livestock Research Institute ILRI (2008).

The IMF Good Governance: The IMF's Role Washington DC: International Monetary Fund (1997) at http://www.imf.org/external/ pubs/ft/exrp/govern/ govindex.htm (accessed 2 July 2007).

United Nations Development Program: "Governance Policy Paper" United Nations Development Program, New York, NY. Available at http://mirror.undp.org/ magnet/policy/ (accessed on 23 May 2011).

The International Convention on Economic and Social Cultural Rights (ICESCR) at http://www2.ohchr.org/english/law/cescr.htm (accessed on 23 May 2011). 